\title{
DAMPAK PENERAPAN INDONESIA - JAPAN ECONOMIC PARTNERSHIP AGREEMENT (IJEPA) TERHADAP NILAI EKSPOR IMPOR INDONESIA
}

\author{
Jesica $^{1}$, Akhmad Syakir Kurnia ${ }^{2}$ \\ Fakultas Ekonomika dan Bisnis Universitas Diponegoro, J1. Prof. Soedarto, \\ Tembalang, Kec. Tembalang, Kota Semarang, Jawa Tengah 50275 \\ jesicasitepuu@gmail.com
}

\begin{abstract}
This study aims to analyze the impact of the IJEPA agreement on bilateral trade (export - import) of Indonesia with Japan using 20 main commodities of trade according to the 2 digit HS code in the period 2001-2018 with the Random Effect Model (REM) estimation model. This study also analyzes whether GDP, population, and the real exchange rate of Indonesia - Japan has an influence on the development of Indonesia's export and import values.

The analysis showed that both before and after the enactment of IJEPA cooperation did not have a significant effect on the value of exports from Indonesia Japan. The variable GDP, population, and the real exchange rate have a significant effect on exports and imports. Therefore, the government of Indonesia and Japan can review the IJEPA agreement in order to increase the benefits of IJEPA.
\end{abstract}

Keywords: IJEPA, Exports-Imports, GDP, Population, Real Exchange Rates, Random Effect Model.

\section{PENDAHULUAN}

Perekonomian negara-negara di dunia semakin terintegrasi sebagai dampak dari adanya globalisasi yang semakin mempermudah arus perpindahan informasi serta barang dan jasa dari satu negara ke negara yang lain. Hal ini yang mendasari perdagangan internasional memegang peranan penting dalam pertumbuhan ekonomi negara-negara di dunia termasuk Indonesia. Perdagangan internasional juga dapat memberikan manfaat bagi suatu negara dengan memproduksi produk yang memiliki keunggulan komparatif serta juga mendapatkan pasar yang lebih luas, namun sebaliknya juga memberikan peluang besar bagi masuknya produk luar negeri yang 
lebih murah dan berkualitas ke pasar domestik. Hal tersebut, membuat setiap negara berlomba untuk melakukan berbagai strategi agar memiliki daya saing yang kuat di pasar internasional.

Pemerintah Indonesia secara agresif membangun beberapa strategi diplomasi dan mengadopsi kebijakan perdagangan yang berwawasan ke luar (outwardlooking policy) melalui serangkaian perjanjian perdagangan bebas (Free Trade Agreement FTA) baik bilateral maupun multilateral, salah satunya adalah Indonesia-Japan Economic. Partnership Agreement (IJEPA). Adanya perjanjian perdagangan bebas dapat memberikan keuntungan secara ekonomi berupa terbukanya akses pasar barang dan jasa dengan adanya penurunan tarif bea masuk dan Non Tariff Measures (NTMs), serta peningkatan investasi (Ardianti, 2015). Penandatanganan perjanjian ini dilakukan oleh kepala negara Indonesia dan Jepang pada tanggal 20 Agustus 2007 di Jakarta dan mulai berlaku efektif pada tanggal 1 Juli 2008. Salah satu unsur utama dalam Perjanjian IJEPA meliputi beberapa sektor adalah Trade in Goods.

Negara Jepang merupakan salah satu negara partner utama bagi Indonesia baik dalam hal perdagangan maupun investasinya. Menurut data dari publikasi Badan Pusat Statistik Indonesia, Jepang merupakan negara tujuan ekspor terbesar kedua bagi Indonesia dengan nilai kontribusi sebesar 10,54 \% dari total nilai ekspor dan juga negara terbesar ketiga sebagai negara asal impor dengan nilai sebesar 9,71\% dari total nilai impor pada tahun 2017. Selain itu, perkembangan ekspor impor Indonesia dengan Jepang berdasarkan produk klasifikasi HS (Harmonized System) 2 digit yang diperoleh dari trademap memperlihatkan bahwa Sebelum implementasi IJEPA perkembangan ekspor impor cenderung mengalami peningkatan di setiap tahunnya, dimana ekspor mencapai 27.743 .856 ribu US\$ dengan nilai rata-rata sebesar 18.222.350 ribu US\$ dan nilai impornya mencapai 15.129.173 ribu US\$ dengan rata-rata 6.685.815 ribu US\$ pada tahun 2008. Pada pasca implementasi IJEPA nilai perdagangan baik ekspor maupun impor terlihat semakin besar dibandingkan pada saat sebelum adanya IJEPA dengan rata-rata ekspor sebesar 22.981.282 ribu US\$ sedangkan rata-rata impor sebesar 16.477.257 ribu US\$.

Berdasarkan uraian data yang telah disajikan diatas maka penelitian ini bertujuan untuk mengetahui sejauh mana dampak dari penerapan Indonesia-Japan Economic Partnership Agreement (IJEPA) terhadap nilai perdagangan IndonesiaJepang yang akan dilihat dari komoditas yang diperdagangkan menurut klasifikasi HS (Harmonized System).

\section{LANDASAN TEORI}

Ekonomi internasional secara keseluruhan adalah gagasan dasar tentang adanya keuntungan perdagangan (gains from trade), yaitu apabila suatu negara menjual barang dan jasa kepada negara lain, maka manfaat atau keuntungannya hampir pasti akan diperoleh kedua belah pihak. Perdagangan menciptakan keuntungan dengan memberikan peluang kepada setiap negara untuk mengekspor berbagai macam barang yang produksinya menggunakan sebagian besar sumber daya yang melimpah di negara yang bersangkutan serta mengimpor berbagai barang yang produksinya menggunakan sumber-sumber daya yang tergolong cukup langka di negara tersebut. Perdagangan internasional memungkinkan setiap negara untuk melakukan 
spesialisasi produksi pada barang-barang yang bisa dibuatnya secara efisien sehingga bisa meningkatkan efisiensi dan skala produksinya (economic of scale). Suatu negara akan melakukan ekspor apabila produksi dalam negeri melebihi konsumsi dalam negeri, sehingga produsen mempunyai peluang untuk memasarkan barangnya ke luar negeri.

Dalam teori perdagangan internasional disebutkan bahwa faktor-faktor yang mempengaruhi ekspor dapat dilihat dari sisi permintaan dan sisi penawaran (Salvatore, 1997). Pada dasarnya, model perdagangan standar harus dilandaskan empat hubungan inti yaitu:

1) Hubungan antara batas-batas kemungkinan produksi dengan kurva penawaran relatif

2) Hubungan antara harga-harga relatif dengan tingkat permintaan

3) Penentuan keseimbangan dunia dengan penawaran relatif dunia dan permintaan relatif dunia

4) Dampak-dampak atau pengaruh nilai tukar perdagangan (term of trade), yakni harga ekspor dari suatu negara dibagi dengan harga impornya terhadap kesejahteraan suatu negara.

Perdagangan bebas adalah sebuah sistem di mana barang, modal, dan aliran tenaga kerja bebas berpindah antara negara-negara tanpa adanya hambatan. Perdagangan bebas juga dapat mendorong kerjasama international dengan membentuk mitra dagang antar negara atau yang biasa disebut integrasi ekonomi. Negara anggota kemitraan dagang tersebut akan saling memberikan kemudahan dalam mempromosikan keunggulan setiap negaranya. Integrasi ekonomi mengacu pada suatu kebijakan komersial atau kebijakan perdagangan yang secara diskriminatif menurunkan atau menghapuskan hambatan-hambatan perdagangan hanya diantara negara-negara yang saling sepakat untuk membentuk suatu integrasi ekonomi terbatas (Salvatore,1997). Menurut Salvatore (1997) tingkatan integrasi ekonomi memiliki beberapa variasi, yaitu: Preferential Trade Arrangements, Free Trade Area, Customs Union, Common Market, dan Economic Union Beberapa manfaat yang bisa diambil dari perdagangan bebas yaitu adanya kerjasama yang baik antara negara negara penganut kerjasama perdagangan bebas, selain itu juga dapat memperoleh barang barang yang tidak bisa diproduksi oleh negara yang tidak mempunyai keunggulan dalam memproduksi suatu barang dan jasa.

Nilai Tukar (exchange rate) atau kurs adalah harga mata uang suatu negara terhadap negara lain atau mata uang suatu negara dinyatakan dalam mata uang negara lain (Salvatore, 1997). Para ekonom membedakan kurs menjadi dua yaitu nilai tukar nominal dan nilai tukar riil. Kurs nominal adalah harga relatif dari mata uang dua negara sedangkan kurs riil (real effective exchange rate) adalah kurs nominal yang sudah dikoreksi dengan harga-harga barang di dalam negeri dibandingkan dengan harga-harga barang di luar negeri. Kurs riil biasa disebut sebagai "terms of trade". kurs riil dapat ditulis dalam perhitungan sebagai berikut.

$$
\text { Kurs Riil }=\frac{\text { Kurs Nominal } x \text { Harga Barang Domestik }}{\text { Harga Barang Luar Negeri }}
$$




$$
\in=e x \frac{P}{P^{*}}
$$

Tingkat harga dimana barang domestik dan barang luar negeri diperdagangkan tergantung pada harga barang dalam mata uang lokal dan pada tingkat kurs yang berlaku. Kurs riil diantara kedua negara dihitung dari kurs nominal dan tingkat harga di kedua negara. Jika kurs riil tinggi, barang-barang luar negeri relatif lebih murah, dan barang-barang domestik relatif lebih mahal. Jika kurs riil rendah, barang-barang luar negeri relatif lebih mahal, dan barang-barang domestik lebih murah (Mankiw, 2007).

Kurs riil tidak berbeda dengan harga relatif. Harga relatif barang domestik dan barang luar negeri mempengaruhi permintaan terhadap barang tersebut. Dalam hal ini, ketika nilai kurs riil rendah maka masyarakat hanya akan membeli sedikit barang impor dikarenakan barang-barang domestik lebih rendah. Untuk alasan yang sama, masyarakat luar negeri akan membeli beraneka macam produk domestik sehingga jumlah ekspor akan mengalami peningkatan. Hal sebaliknya akan terjadi jika nilai kurs riil tinggi. Barang-barang domestik akan cenderung lebih mahal dibandingkan dengan barang-barang luar negeri sehingga masyarakat akan lebih memilih membeli barang impor sehingga ekspor akan mengalami penurunan (Mankiw, 2007).

\section{METODE PENELITIAN}

\section{Variabel Penelitian dan Definisi Operasional}

Berikut merupakan definisi variabel yang akan dijelaskan dalam penelitian ini:

a. Ekspor dan Impor

Ekspor adalah penjualan barang dalam negeri ke pasar luar negeri. Artinya terdapat permintaan pasar luar negeri atas produk domestik. Sedangkan impor adalah kebalikannya, yaitu pembelian barang dari luar negeri, artinya terdapat permintaan domestik atas barang dari luar negeri.

\section{b. Gross Domestic Product (GDP) atau Produk Domestik Bruto}

Gross Domestic Product (GDP) atau produk domestik bruto adalah nilai dari seluruh produk yang dihasilkan oleh seluruh produk yang dihasilkan oleh seluruh pelaku ekonomi dalam suatu negara dalam satu tahun. Nilai GDP yang digunakan dalam penelitan ini adalah nilai GDP negara Indonesia (untuk impor) dan Jepang (untuk ekspor) menggunakan nilai GDP riil yang diukur dalam satuan U\$ dollar.

\section{c. Nilai Tukar Riil Rupiah Indonesia Terhadap Yen Jepang (KURS)}

Nilai tukar riil Rupiah Indonesia terhadap Yen Jepang (KURS) adalah pengukuran nilai tukar nominal yang telah disesuaikan dengan perbedaan harga di Jepang dan Indonesia. 
d. Populasi Penduduk Indonesia dan Jepang

Populasi adalah jumlah penduduk yang berdomisili dan menetap di suatu wilayah. Dalam penelitian ini jumlah penduduk Indonesia dan Jepang akan di analisis dari sisi yang berbeda. Dimana jumlah penduduk Indonesia akan dianalisis dalam sisi impor sedangkan jumlah penduduk Jepang akan dianalisis dalam sisi ekspor sebagai pangsa pasar Indonesia di Jepang.

\section{e. Indonesia-Japan Economic Partnership Agreement (IJEPA)}

Pemberlakuan IJEPA merupakan variabel yang berbentuk data kualitatif. Agar dapat digunakan dalam persamaan regresi, variabel dummy ini, ditransformasikan datanya menjadi data biner yang bernilai 0 atau 1 .

\section{JENIS DAN SUMBER DATA}

Jenis data yang digunakan adalah data sekunder, yaitu berupa data time series dan cross section. Data cross section yang digunakan dalam penelitian ini sebanyak 20 komoditas dengan rentang tahun 2001 sampai dengan tahun 2018.

\section{METODE ANALISIS}

Metode analisis yang digunakan dalam penelitian ini adalah metode kuantitatif dengan menggunakan Regresi. Pendekatan yang digunakan untuk mengestimasi parameter model adalah pendekatan data panel (pool data) Random Effect Model (REM), dimana data panel adalah gabungan antara data silang (cross section) dengan data runtut waktu (time series). Model REM menggunakan error yang diduga memilki hubungan antarwaktu dan antar individu. Oleh karenanya, REM mengasumsikan bahwa setiap individu memiliki perbedaan intersep yang merupakan variabel random (Gujarati \& Porter, 2012). Metode yang tepat untuk mengestimasi model ini adalah dengan metode generalized least squares (GLS), dengan begitu permasalahan autokorelasi dan heterokedastisitas otomatis telah teratasi. Berdasarkan variabel-variabel yang digunakan maka model persamaan regresinya sebagai berikut:

Dimana:
a. Export $_{i t}=\beta_{0}+\beta_{1} \mathrm{GDPJ}_{i t}+\beta_{2} \mathrm{KURS}_{i t}+\beta_{3} \mathrm{POPJ}_{i t}+\beta_{4} \mathrm{IJEPA}_{i t}+\mathrm{w}_{i t}$
b. Import $_{i t}=\beta_{0}+\beta_{1} \mathrm{GDPI}_{i t}+\beta_{2} \mathrm{KURS}_{i t}+\beta_{3} \mathrm{POPI}_{i t}+\beta_{4} \mathrm{IJEPA}_{i t}+\mathrm{w}_{i t}$

Export

Import

GDPJ

GDPI

KURS

POPJ

POPI

IJEPA

$\beta_{0}, \beta_{1}, \beta_{2}, \beta_{3}, \beta_{4}$

$\mathrm{w}_{i t}$
= Nilai ekspor riil Indonesia ke Jepang

$=$ Nilai impor riil Indonesia dari Jepang

$=$ GDP riil Jepang

$=$ GDP riil Indonesia

= Nilai Tukar Riil Rupiah (Rp) terhadap Yen Jepang (¥)

$=$ Jumlah penduduk Jepang

$=$ Jumlah penduduk Indonesia

= Dummy variable $($ IJEPA=1; sebelum IJEPA=0)

$=$ Parameter regresi ganda

$=\varepsilon_{\mathrm{i}}+\mathrm{u}_{\mathrm{i} t \text {, }}$ error term gabungan 


\section{HASIL PENELITIAN DAN PEMBAHASAN}

\section{Perkembangan Perdagangan Indonesia Dengan Jepang}

Gambar 1 menunjukkan perkembangan ekspor impor Indonesia dengan Jepang berdasarkan produk klasifikasi HS (Harmonized System) 2 digit. Dalam gambar tersebut dapat dilihat perkembangan ekspor impor Indonesia dengan Jepang baik sebelum implementasi IJEPA maupun setelah implementasi IJEPA.

\section{Gambar 1 \\ Perkembangan Ekspor dan Impor Indonesia-Jepang Tahun 2001-2018 (dalam US\$)}

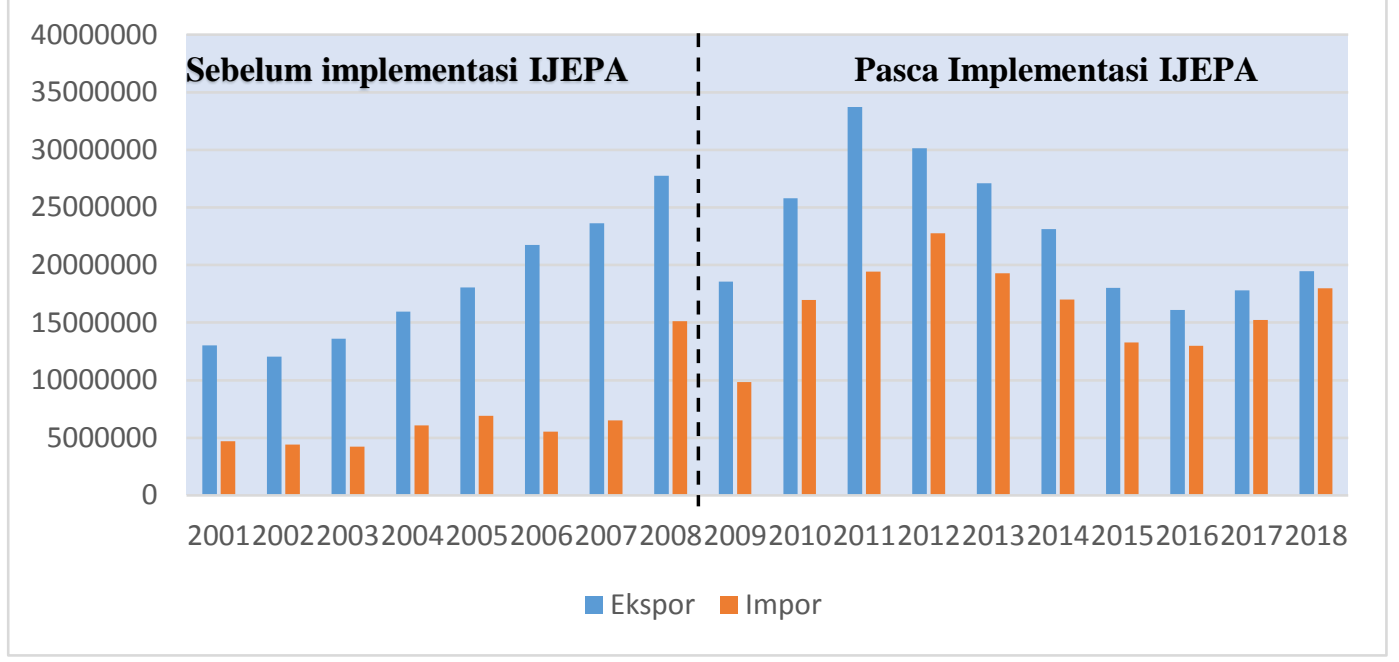

Sumber: Trademap (sudah diolah)

Perkembangan ekspor dan impor Indonesia dengan Jepang dari tahun 2001 sampai dengan 2018 cenderung mengalami fluktuasi yang sama. Dari sisi ekspor, nilai yang ditunjukkan baik sebelum IJEPA (tahun 2001-2008) maupun setelah diberlakukannya IJEPA (tahun 2009-2018) tidak terlalu menunjukkan perubahan yang besar walaupun jika dilihat dari nilai rata-rata mengalami peningkatan dari US\$ 18.222.350,3 menjadi US\$ 22.981.282,1. Berbeda dengan sisi impor yang dapat dilihat mengalami peningkatan setelah pemberlakuan IJEPA walaupun mengalami fluktuasi naik-turun di setiap tahunnya. Rata-rata impor sebelum IJEPA ialah sebesar US\$ 6.685.814,6 mengalami peningkatan yang sangat besar setelah diberlakukannya IJEPA menjadi US\$ 16.477. 257.

Dengan membandingkan nilai ekspor dan impor sebelum IJEPA dan pasca implementasi IJEPA, secara sekilas dapat dilihat bahwa nilai ekspor dan impor memiliki perbedaan perubahan yang sangat signifikan. Dimana pada pasca implementasi IJEPA, nilai rata-rata impor meningkat lebih dari dua kali lipat dari sebelum adanya implementasi IJEPA, sedangkan ekspor mengalami peningkatan yang lebih kecil dari peningkatan nilai impor pasca implementasi IJEPA. 


\section{Gambar 2 \\ Komoditas Utama Impor Indonesia dengan Jepang Tahun 2018 (Menurut Kode HS Dua Digit)}

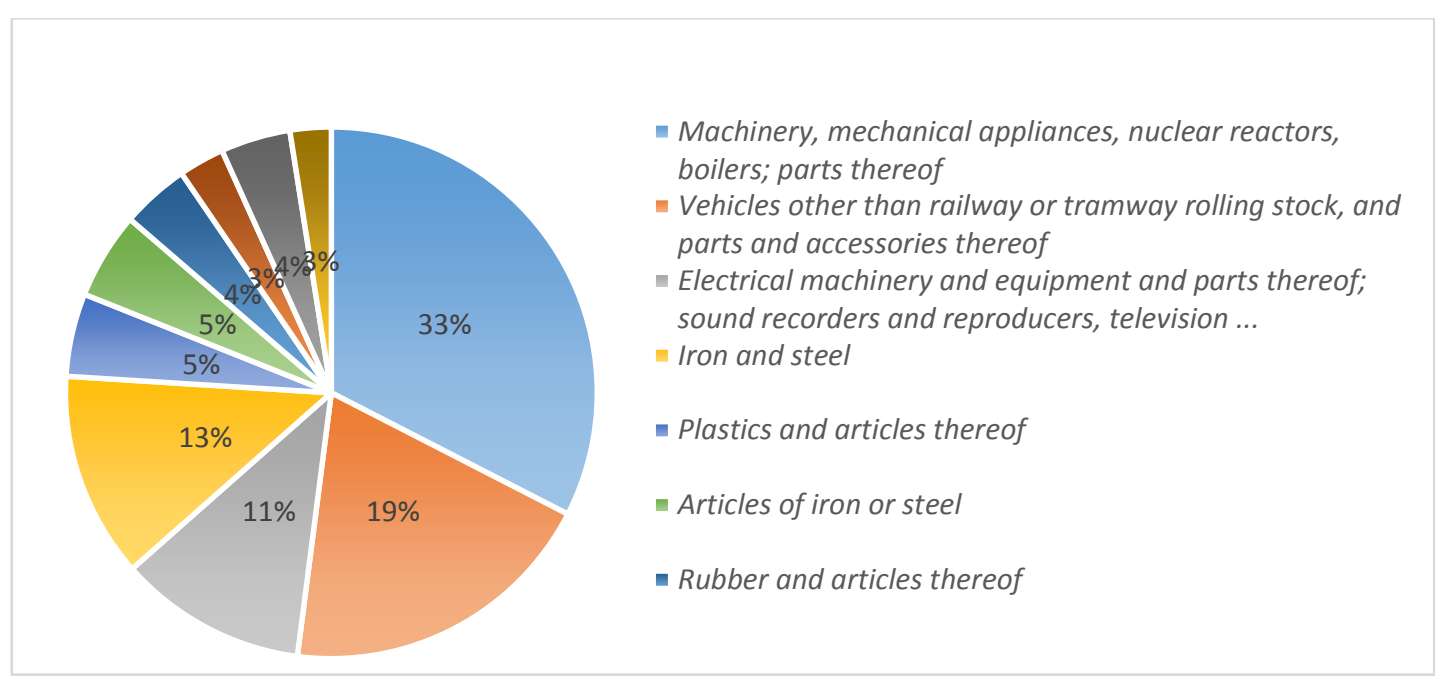

Sumber: Trademap (sudah diolah)

Dalam gambar diatas dapat dilihat impor komoditas apa saja yang menjadi utama dari Jepang ke Indonesia. Menurut data yang diperoleh dari Trademap, 10 komoditas utama yang diimpor oleh Indonesia dari Jepang didominasi oleh Machinery, mechanical appliance, nuclear reactors, boilers;parts thereof dengan porsi sebesar 33\% dengan nilai US\$ 4.855.956 ribu dan komoditi dengan nilai terkecil adalah optical photographic, cinematographic, measuring, checking, precision, medical or surgical dengan porsi sebesar 3\% dengan nilai US\$ 415.818 ribu. 10 komoditas ini merepresentasikan kurang lebih $90 \%$ dari total impor Indonesia dari Jepang.

Berbeda dengan gambar 2, dalam gambar 3 terlihat 10 komoditas utama ekspor Indonesia ke negara Jepang. Menurut data dari Trademap, komoditas ekspor Indonesia ke Jepang didominasi oleh komoditas mineral fuels, mineral oils and product of their distillation; bituminous substance;mineral yaitu sebesar $42 \%$ dengan nilai US\$ 5.961.225 ribu. Sedangkan komoditas yang terkecil dari 10 komoditas utama tersebut adalah komoditas fish and crustaceans, molluscs and other aquatic invertebrates memiliki porsi sebesar 3\% dengan nilai US\$ 496.162 ribu. 


\section{Gambar 3 Komoditas Utama Ekspor Indonesia dengan Jepang Tahun 2018 (Menurut Kode HS Dua Digit)}

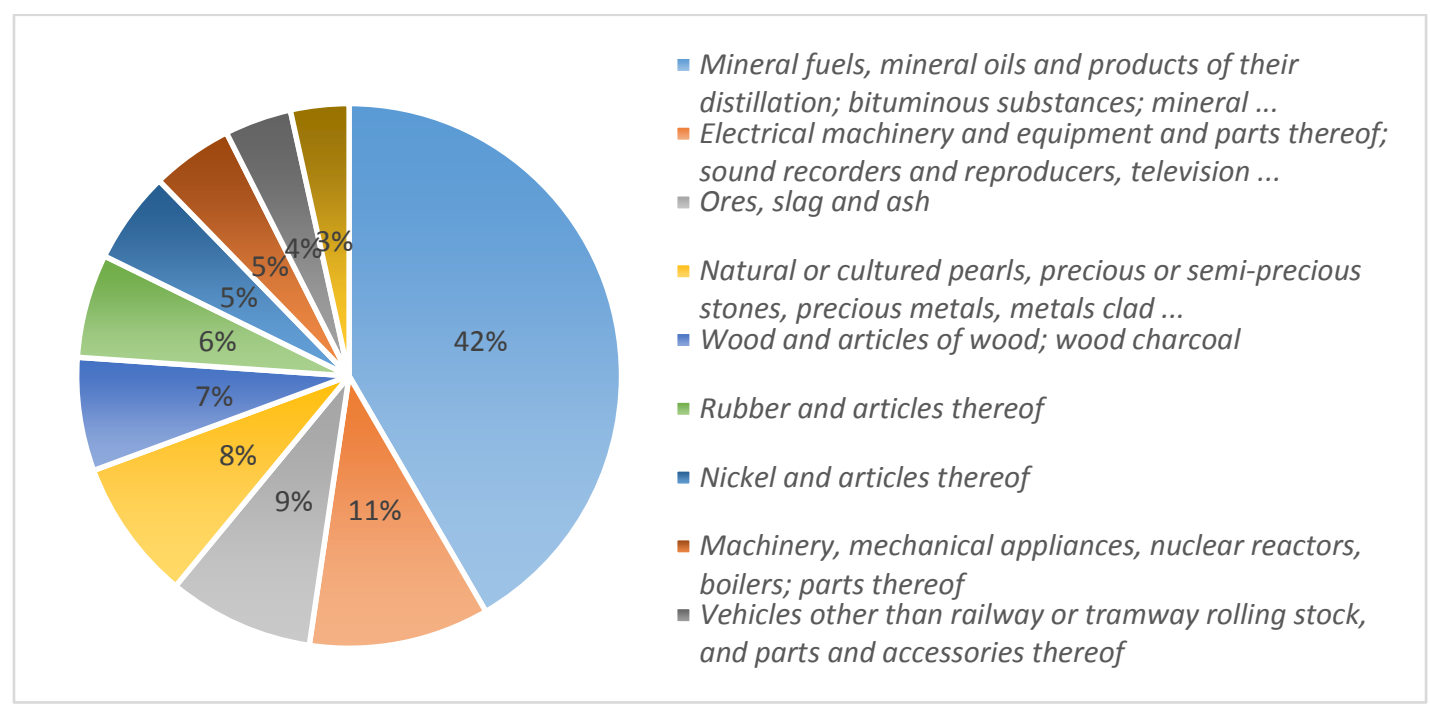

Sumber: Trademap (sudah diolah)

\section{Hasil Regresi Random Effect Model}

Berdasarkan prosedur pemilihan model yang dilakukan dengan menggunakan Hausman, model estimasi yang terbaik untuk mengetahui dampak pemberlakuan IJEPA terhadap nilai ekspor dan impor Indonesia menggunakan REM (Random Effect Model). Uji Hausman yang menghasilkan nilai probabilitas F stat lebih besar dari $\alpha=0,05$ menghasilkan keputusan bahwa metode REM signifikan dalam menguji data panel, dan sebaliknya. Nilai probabilitas dari model adalah tidak signifikan sebesar 1,000 sehingga dapat disimpulkan bahwa dari hasil uji Hausman menunjukkan bahwa model penelitian yang terbaik untuk mengetahui dampak pemberlakuan IJEPA terhadap nilai ekspor dan impor Indonesia menggunakan REM. Adapun hasil estimasi untuk ekspor akan dijelaskan pada tabel 1 sedangkan impor akan ditampilkan pada tabel 2.

Berdasarkan tabel hasil ringkasan regresi REM pada tabel 1, terlihat jika terdapat tiga variabel independen yang memiliki pengaruh terhadap variabel dependen, yaitu GDPJ, yang berpengaruh positif, KURS yang berpengaruh negatif, serta POPJ yang berpengaruh negatif. Hasil uji t-statistik menunjukkan bahwa mengacu pada nilai signifikansi $\alpha=5 \%$ maka estimasi Ekspor dengan REM menunjukkan bahwa tiga variabel independen yaitu GDP Jepang, Kurs riil Indonesia, dan Populasi penduduk Jepang berpengaruh secara signifikan terhadap nilai ekspor, dimana GDP Jepang berpengaruh secara positif dan signifikan terhadap ekspor, sedangkan Kurs dan Populasi Jepang berpengaruh negatif dan signifikan mempengaruhi nilai ekspor. Sementara itu, variebel dummy IJEPA memiliki pengaruh yang positif akan tetapi tidak signifikan terhadap nilai ekspor, dibuktikan dengan nilai probabilitas diatas $5 \%$ yang artinya menerima $\mathrm{H} 0$. 
Tabel 1 Ringkasan Hasil Regresi Random Effect Model Panel Data Ekspor

\begin{tabular}{cccc}
\hline Variabel & Koefisien & t-Statistik & Prob \\
\hline C & 425.100 & $3.573^{*}$ & 0.0004 \\
GDPJ & 1.704 & $3.526^{*}$ & 0.0005 \\
KURS & -0.004 & $-4.621^{*}$ & 0.0000 \\
POPJ & -53.957 & $-3.575^{*}$ & 0.0004 \\
DIJEPA & 0.016 & 0.231 & 0.817 \\
\hline
\end{tabular}

\begin{tabular}{cc}
\hline R-squared & 0.299 \\
Adjust R- & 0.291 \\
squared & 37.869 \\
F-statistic & 0.000 \\
Prob(F-statistic) & \\
\hline
\end{tabular}

Keterangan: *Signifikan pada $\alpha=5 \%$.

Tabel 2

Ringkasan Hasil Regresi Random Effect Model Panel Data Impor

\begin{tabular}{cccc}
\hline Variabel & Koefisien & t-Statistik & Prob \\
\hline C & -73.941 & $-4.696^{*}$ & 0.000 \\
GDPI & 2.441 & $5.021^{*}$ & 0.000 \\
KURS & 0.006 & $0.002^{*}$ & 0.002 \\
POPI & 6.527 & $4.012^{*}$ & 0.0001 \\
DIJEPA & 0.0003 & 0.004 & 0.997 \\
\hline R-squared & 0.473 & & \\
Adjust R-squared & 0.467 & & \\
F-statistic & 77.997 & & \\
Prob(F-statistic) & 0.000 & & \\
\hline
\end{tabular}

Keterangan: *Signifikan pada $\alpha=5 \%$.

Disisi lain, untuk hasil estimasi REM pada Impor yang ditampilkan pada tabel 2 menunjukkan bahwa variabel independen yang signifikan memiliki pengaruh terhadap impor pun sama dengan estimasi pada model ekspor, yaitu GDPI, KURS, dan POPI atau bisa dikatakan menolak H0. GDP Indonesia, Kurs riil Indonesia dan Populasi Indonesia secara bersamaan memiliki pengaruh yang positif dan signifikan terhadap nilai impor pada nilai signifikansi $\alpha=5 \%$. Variabel dummy IJEPA dalam model impor juga memiliki pengaruh yang positif akan tetapi tidak signifikan pada nilai signifikansi $5 \%$ yang artinya menerima $\mathrm{H} 0$. 
Uji koefisien regresi serentak baik untuk persamaan model ekspor maupun impor juga dapat dilihat pada kedua tabel. Uji koefisien regresi serentak digunakan untuk menguji apakah secara simultan variabel independen memiliki pengaruh terhadap variabel dependen. Diketahui bahwa estimasi pada uji $\mathrm{F}$ dalam persamaan ekspor menunjukkan nilai sebesar 37,867 dan nilai probabilitas sebesar 0,000, dengan taraf $\alpha=5 \%$ maka dapat disimpulkan bahwa secara simultan nilai koefisien hasil regresi dalam persamaan model ekspor tidak sama dengan nol dan secara signifikan semua variabel independen (GDP riil Jepang, Kurs riil Indonesia, Jumlah penduduk Jepang, dan Perjanjian IJEPA) memiliki pengaruh terhadap nilai variabel dependen. Dalam persamaan model impor juga terjadi hal yang sama dimana pada uji $\mathrm{F}$ menunjukkan nilai sebesar 77,997 dan nilai probabilitasnya sebesar 0,000. dengan taraf $\alpha=5 \%$ maka dapat disimpulkan bahwa secara simultan nilai koefisien hasil regresi dalam model impor tidak sama dengan nol dan secara signifikan variabel independen (GDP riil Indonesia, Kurs riil Indonesia, Jumlah penduduk Indonesia, dan Perjanjian IJEPA) memiliki pengaruh terhadap nilai variabel dependen.

Goodness of fit atau ukuran kesesuaian model diukur berdasarkan $R^{2}$ (nilai koefisien determinasi). Nilai koefisien determinasi berdasarkan estimasi random effect pada persamaan ekspor menunjukan nilai sebesar 30\%. Hal ini menunjukkan bahwa variasi dari variabel independen di model ekspor mampu menjelaskan variasi variabel dependennya sebesar $30 \%$. Sedangkan dalam model impor, kemampuan untuk menjelaskan sebesar $47 \%$. Kemampuan menjelaskan baik dari sisi ekspor maupun impor masih bertaraf nol namun sudah mendekati satu yang artinya sudah cukup untuk menjelaskan terhadap variabel independen.

Dari hasil estimasi menggunakan model REM yang telah diperoleh sebelumnya dalam model ekspor maupun impor diketahui bahwa:

1. Pendapatan Nasional negara Indonesia dan Jepang memiliki pengaruh yang signifikan positif terhadap nilai ekspor dan impor Indonesia. Hal ini membuktikan bahwa teori permintaan yang menyebutkan bahwa peningkatan atau kenaikan pendapatan seseorang ataupun suatu negara akan berdampak pada peningkatan konsumsi orang atau negara tersebut. Dimana dari hasil estimasi dapat dilihat peningkatan GDP Jepang akan meningkatkan ekspor Indonesia, sedangkan peningkatan GDP Indonesia meningkatkan impor Indonesia.

2. Perlakuan Kurs riil Indonesia - Jepang berbeda di kedua sisi, dimana pada sisi ekspor, peran kurs akan berdampak negatif terhadap nilai ekspor sedangkan terhadap nilai impor memberikan dampak yang positif. Ini membuktikan teori yang sebelumya telah disebutkan dimana ketika nilai kurs riil rendah maka masyarakat hanya akan membeli sedikit barang impor dikarenakan barangbarang domestik lebih rendah, dan masyarakat luar negeri akan membeli beraneka macam produk domestik sehingga jumlah ekspor akan mengalami peningkatan. Hal sebaliknya akan terjadi jika nilai kurs riil tinggi. Barangbarang domestik akan cenderung lebih mahal dibandingkan dengan barangbarang luar negeri sehingga masyarakat akan lebih memilih membeli barang impor sehingga ekspor akan mengalami penurunan. 
3. Jumlah penduduk negara Jepang yang diasumsikan akan meningkatkan market size negara tersebut, justru terlihat memberikan pengaruh yang negatif. Artinya dalam kasus negara Jepang, membuktikan bahwa tidak selalu peningkatan jumlah penduduk suatu negara akan meningkatkan jumlah konsumsi negara tersebut. Berbeda dalam kasus negara Indonesia, dengan melihat hasil estimasi dari sisi impor peningkatan atau kenaikan jumlah penduduk Indonesia akan meningkatkan nilai impor Indonesia dari negara Jepang. Hal ini membuktikan hipotesis bahwa kenaikan jumlah penduduk Indonesia akan meningkatkan market size atau pangsa pasar produk-produk Jepang di Indonesia.

4. Dampak dari adanya perjanjian bilateral antara Indonesia dan Jepang (IJEPA) diharapkan dapat memberikan keuntungan bagi kedua negara terkhusus juga Indonesia. Dengan adanya pembebasan tarif yang dilakukan diharapkan dapat meningkatkan nilai perdagangan dari kedua negara tersebut. Akan tetapi jika dilihat dari hasil estimasi baik dari sisi ekspor maupun impor, IJEPA tidak terlalu memberikan pengaruh yang signifikan terhadap ekspor maupun impor Indonesia dengan Jepang.

\section{KESIMPULAN}

Berdasarkan hasil penelitian dapat disimpulkan bahwa Pendapatan masingmasing negara Indonesia maupun Jepang, nilai tukar riil mata uang Indonesia dengan Jepang dan juga populasi penduduk kedua negara memiliki pengaruh terhadap perkembangan nilai ekspor dan impor Indonesia dengan Jepang. Sedangkan untuk IJEPA sendiri, dari hasil yang terlihat dapat disimpulkan bahwa adanya kerjasama IJEPA tidak memberikan pengaruh yang signifikan bagi ekspor dan impor Indonesia dengan Jepang.

Perjanjian kerjasama Indonesia Japan Economic Partnership Agreement (IJEPA) yang implementasinya dimulai pada Juli 2008, dengan salah satu pilar utama yaitu liberalisasi dimana penghapusan dan penurunan tarif bea masuk untuk beberapa pos tarif yang telah disepakati bersama oleh Indonesia dan Jepang di awal kesepakatan. Akan tetapi, bagi Indonesia sendiri harapan akan keuntungan dalam peningkatan aktifitas ekspor produk unggulan Indonesia ke Jepang seperti hasil-hasil sumber daya alam yaitu hasil pertanian, perkebunan, hasil hutan dan hasil laut dalam IJEPA belum memberikan manfaat yang besar. Sekalipun tidak dikenakan tarif bea masuk, tetapi tarif bukanlah satu-satunya hambatan, ketika tarif sudah tidak ada, Jepang menggunakan standarisasi untuk mencegah banjirnya produk-produk Indonesia di dalam pasarnya. Selain itu, neraca perdagangan Indonesia dengan Jepang juga dapat dilihat mengalami kerugian atau defisit setelah adanya kesepakatan IJEPA. Hal ini dikarenakan perumusan kerjasama IJEPA yang belum mendetail dan pemerintah Indonesia tidak memperhatikan bagaimana perbedaan level perekonomian Indonesia dengan negara Jepang yang selanjutnya akan berpengaruh terhadap perkembangan ekspor dan impor. 
Ketidakberhasilan dari kerjasama IJEPA ini juga diungkapkan dalam laporan akhir analisis review IJEPA dalam perdagangan barang yang dikeluarkan oleh Kementrian Perdagangan RI. Dimana dalam laporan tersebut menyebutkan bahwa produk-produk ekspor Indonesia mengalami penurunan daya saing di pasar Jepang, begitu juga dengan negara Jepang yang mengalami penurunan daya saing sehingga menjadi tidak kompetitif di pasar Indonesia.

\section{DAFTAR PUSTAKA}

Ardianti, Septika Tri. 2015. Dampak Perjanjian Perdagangan Indonesia-Jepang (IJEPA) Terhadap Kinerja Perdagangan Bilateral. Buletin Ilmiah Litbang Perdagangan, 9(2), 129-151.

Ghozali, Imam dan Ratmono, Dwi, 2013. Analisis Multivariat dan Ekonometrika: Teori, Konsep dan Aplikasi dengan EViews 8, ISBN, UNDIP Semarang.

Gujarati, D. N., \& Porter, D. C. (2009). Basic Econometrics (5th ed.). New York: McGraw-Hill.

Gujarati, Damodar N. (2012). Dasar-dasar Ekonometrika (Buku 2 Edisi Kelima). (Raden Carlos Mangunsong, Penerjemah). Jakarta: Salemba Empat.

Kementerian Perdagangan. 2007. Agreement Between The Republic Of Indonesia and Japan For an Economic Partnership (IJEPA) http://www.kemendag.go.id/en/perdagangan kita/agreements.

Kementerian Perdagangan, 2015. Analisis Review Indonesia Japan Economic Partnership Agreement (IJEPA) Dalam Perdagangan Barang, Jakarta.

Kementerian Perdagangan, 2018. Factsheet Indonesia-Japan Economic Partnership Agreement (IJEPA), Jakarta.

Mankiw, N. Gregory (2007). Makroekonomi (Edisi Keenam). (Fitria Liza, SE, alih bahasa). Jakarta: Penerbit Erlangga.

Salvatore, Dominick (1997). Ekonomi Internasional (Edisi Kelima). Jilid Satu. Jakarta: Penerbit Erlangga.

Winarno, Wing Wahyu. (2009). Analisis Ekonometrika dan Statistika Dengan Eviews. Sekolah Tinggi Ilmu Manajemen YKPN. Yogyakarta 